\title{
Concentrations of interleukin 6 and tumour necrosis factor in serum and stools of children with Shigella dysenteriae 1 infection
}

D G Harendra de Silva, L N Mendis, N Sheron, G J M Alexander, D C A Candy, H Chart, B Rowe

\begin{abstract}
Serum interleukin 6 (IL-6) and tumour necrosis factor (TNF) were measured in children with dysentery during an epidemic caused by Shigella dysenteriae 1. IL-6 and TNF were also measured in fresh stool filtrates from children with acute gastroenteritis. The median serum IL-6 concentration was raised significantly in the children with complications (haemolytic uraemic syndrome, leukemoid reaction, thrombocytopenia, thrombocytosis, and severe colitis lasting more than one week) during the first week $(\mathrm{n}=18,9-7728 \mathrm{pg} / \mathrm{ml}$; median 107) and in the second week $(n=13,5-$ $312 \mathrm{pg} / \mathrm{ml}$; median 77), compared with convalescent sera $(\mathbf{n}=10,<3-85 \mathrm{pg} / \mathrm{ml}$; median 39 ; $\mathbf{p}<0.02$ and $<0.05$ respectively). The median IL-6 concentration during the first week was significantly higher in the group with complicated disease than in those with no complications $(\mathrm{n}=8,<3-37 \mathrm{pg} / \mathrm{ml}$; median $5 ; \mathrm{p}<0.001)$. Although serum TNF concentrations were significantly raised in the complicated group during the first and second weeks of the illness and in the uncomplicated group compared with convalescence, there was no significant difference in the TNF concentrations between the complicated and uncomplicated groups. IL-6 was detectable in stool filtrates from eight of 13 children with $S$ dysenteriae 1 infection and four of eight children with $S$ flexneri infection. It was not detectable in Cryptosporidia, rotavirus, or adenovirus infections, those with pathogen-negative acute diarrhoea or controls. Seven of 13 children with $S$ dysenteriae 1 and three of nine children with $S$ flexneri infections had TNF detectable in stools. Two of four children with adenovirus infection also had TNF detected in stools. None of the children with Salmonella, Cryptosporidia, rotavirus or children with pathogen-negative diarrhoea and controls had detectable TNF in stool filtrates. It is postulated that the local and generalised vasculitis observed in shigellosis may be related to a direct effect of Shiga toxin on endothelial cells or caused by cytokine production stimulated by endotoxin, or both.

(Gut 1993; 34: 194-198)
\end{abstract}

Central Public Health Laboratory, Colindale

H Chart

B Rowe

Correspondence to:

Professor D C A Candy,

Department of Child Health,

King's College School of

Medicine and Den

London SE5 8RX.

Accepted for publication

21 July 1992
Most children with dehydration caused by watery diarrhoea can be effectively treated with oral rehydration therapy. By contrast mortality from bacterial dysentery still occurs primarily in patients with Shigella dysenteriae 1 infections. The problem of dehydration is eclipsed by the systemic effects of the infection that include haemolytic uraemic syndrome.' In Galle, Sri Lanka, $5-10 \%$ of children admitted with bacterial dysentery during epidemics develop haemolytic uraemic syndrome (unpublished observations). Rahaman et al $^{2}$ first reported the association between $S$ dysenteriae 1 infection and haemolytic uraemic syndrome. A potential common factor between haemolytic uraemic syndrome associated with infections caused by $S$ dysenteriae 1 and certain strains of Escherichia coli (most notably $E$ coli serotype $\mathrm{O} 157: \mathrm{H} 7)^{3}$ is the production of a cytotoxic enterotoxin (Shiga toxin and Verotoxin respectively). Shiga toxin and Verotoxin (VT) share biological effects that may be related to their ability to inhibit protein synthesis. ${ }^{45}$

The release of endotoxin during shigellosis could also damage the capillary endothelium, either as part of a generalised Schwartzman reaction ${ }^{6}$ or as a result of release of cytokines such as tumour necrosis factor $(\mathrm{TNF})^{7}$ or interleukin 6 (IL-6). ${ }^{8}$ We therefore measured IL-6 and TNF concentrations in serum and stool from children with bacterial dysentery to determine whether there was a correlation between these measurements and the severity of the disease and appearance of complications, especially haemolytic uraemic syndrome.

\section{Methods}

\section{PATIENTS}

Forty children with clinical dysentery were admitted to the University Paediatric Unit, Teaching Hospital, Karapitiya, Galle, Sri Lanka, during an epidemic of bacillary dysentery caused by $S$ dysenteriae 1 . Blood samples were taken from the children when they were bled for routine investigations, centrifuged within 30 minutes, and the serum was frozen and stored at $-70^{\circ}$. The diagnosis of $S$ dysenteriae 1 was established by positive stool cultures or by significantly positive concentrations of $\operatorname{IgM}$ antibodies to the endotoxin of $S$ dysenteriae 1 , measured by ELISA and confirmed by immunoblotting, by methods similar to those used for serological diagnosis of $E$ coli $\mathrm{O} 157: \mathrm{H} 7$ infection. ${ }^{9}$ Children were divided into a 'complicated' group (aged 7-132 months; median 48) if adverse prognostic features were present including haemolytic uraemic syndrome $(n=4)$ microangiopathic haemolytic anaemia $(\mathrm{n}=1)$, leukemoid reactions (neutrophil count $>20 \times 10 \% /$ $\mathrm{n}=5$ ), thrombocytopenia (platelet count $<100 \times 10^{4} / 1 ; \mathrm{n}=1$ ), or thrombocytosis (platelet count $>400 \times 10^{\prime} / 1 ; n=2$ ) and severe colitis 
associated with diarrhoea lasting for more than 7 days $(\mathrm{n}=18) .{ }^{210}$ Haemolytic uraemic syndrome was diagnosed if the blood urea was $>25 \mathrm{mmol} / \mathrm{l}$, platelet count $100 \times 10^{9} / 1$, and there was evidence of microangiopathic anaemia on blood film. Children with diarrhoea lasting less than 7 days and without any apparent complications, were included in the 'uncomplicated' group $(n=9$; age 24-84 months; median 60). Blood samples were also taken from 12 'convalescent' patients (age 13-132 months; median 54) from the complicated group before discharge from hospital, 1 to 2 days after the diarrhoea had stopped.

Fresh stools from 49 children with acute gastroenteritis were examined by standard methods in the Department of Microbiology University of Colombo, Sri Lanka for Salmonella, Shigella, Aeromonas, Vibrio cholerae, enterotoxigenic $E$ coli (ETEC; LT and ST), enteropathogenic $E$ coli (EPEC), Campylobacter, rotavirus (ELISA) adenovirus (ELISA), and Cryptosporidia. A measured aliquot of stool was diluted in PBS, filtered through a micropore filter, and frozen at $-70^{\circ} \mathrm{C}$. Control stools from children without diarrhoea were processed identically. The serum and stool filtrate samples were transported to the UK in dry ice.

\section{CYTOKINE ASSAYS}

Serum and stool IL-6 and stool TNF concentrations were measured using commercial quantitative 'sandwich' enzyme immunoassays (Quantikine, R\&D Systems Ltd, MI, USA). TNF concentrations were estimated in serum using the L929 bioassay. ${ }^{.1}$

\section{STATISTICAL METHODS}

Analyses were performed by the Mann-Whitney U test.

Ethical permission was obtained from the Ethical Committees of the Faculty of Medicine, University of Rahuna, Galle, Sri Lanka and King's College School of Medicine and Dentistry, London, UK.

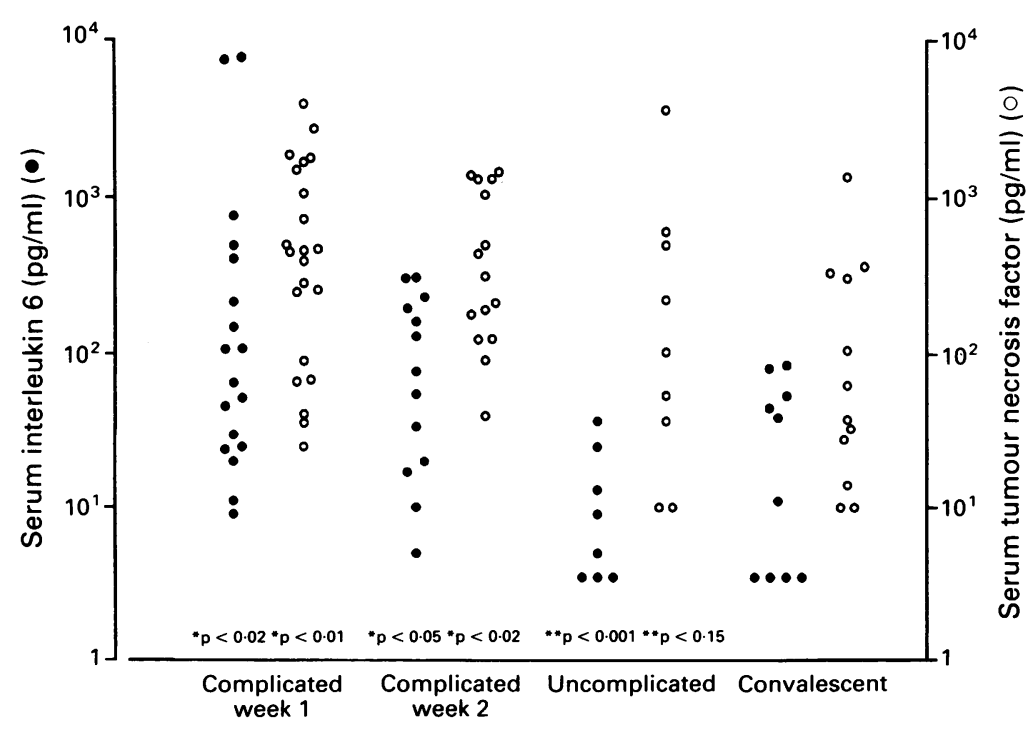

Figure 1: Serum concentrations of interleukin $6(I L-6)$ and TNF in children with bacterial dysentery. ${ }^{\star}=$ Complicated $\mathrm{v}$ convalescence; ${ }^{\star \star}=$ complicated week $1 \mathrm{v}$ uncomplicated.

\section{Results}

\section{SERUM IL-6 AND TNF}

Blood samples for IL-6 and TNF measurements were taken at times of venepuncture for clinical indications, and sample volumes were limited. Patients were not studied after discharge from hospital and hence complete data on IL- 6 and TNF concentrations were not available throughout the illness. The median serum IL-6 concentration was raised significantly in the children with a complicated course during the first week $(\mathrm{n}=18,11-7728 \mathrm{pg} / \mathrm{ml}$; median 86$)$ and in the second week $(\mathrm{n}=13,5-312 \mathrm{pg} / \mathrm{ml}$; median 77$)$, compared with convalescent sera $(n=10,<13-$ $85 \mathrm{pg} / \mathrm{ml}$; median 39; $\mathrm{p}<0.02$ and $<0.05$ respectively; Figs 1-3). The median IL-6 concentration during the first week was significantly higher in the complicated compared with the uncomplicated group $(\mathrm{n}=8,<3-37 \mathrm{pg} / \mathrm{ml}$; median 5; $\mathrm{p}<0.001)$. Serum TNF concentrations were significantly raised in the complicated group during the first week $(\mathrm{n}=22,25-3942 \mathrm{pg} / \mathrm{ml}$; median $451 \mathrm{pg} / \mathrm{ml}$ ) and in the second week of the illness $(\mathrm{n}=15,40-1462 \mathrm{pg} / \mathrm{ml}$; median $317 \mathrm{pg} /$ $\mathrm{ml})$ when compared with convalescence $(\mathrm{n}=12$, $<10-1368 \mathrm{pg} / \mathrm{ml}$; median $63 \mathrm{pg} / \mathrm{ml} ; \mathrm{p}<0.01$ and $<0.02$ respectively). The median serum TNF concentration was also raised in the uncomplicated group $(\mathrm{n}=9,<10-3613 \mathrm{pg} / \mathrm{ml}$; median 103 $\mathrm{pg} / \mathrm{ml}$ ), but there was no statistically significant difference in the TNF concentrations between the complicated and uncomplicated groups $(p<0 \cdot 15)$. One patient whose serum concentration of TNF was very high $(1368 \mathrm{pg} / \mathrm{ml})$ during convalescence had had disseminated intravascular coagulation during the acute phase.

\section{STOOL IL-6 AND TNF}

IL-6 was measured in stool filtrates from 48 children and was detectable in filtrates from eight of 13 children with $S$ dysenteriae 1 infection (20$8044 \mathrm{pg} / \mathrm{ml}$ ), and four of eight children with $S$ flexneri $(12-68 \mathrm{pg} / \mathrm{ml}$ ) infection. IL-6 was also detected in the one patient with $S$ sonnei infection $(24 \mathrm{pg} / \mathrm{ml})$ and was just detectable $(6 \mathrm{pg} / \mathrm{ml})$ in one patient with Salmonella infection. It was not detectable in Cryptosporidia $(n=5)$, rotavirus $(n=4)$, or adenovirus $(n=4)$ infections, those with acute diarrhoea in whom no pathogen was detected $(n=4)$, or healthy control children (Fig 4).

Seven of 13 children with $S$ dysenteriae 1 and three of nine children with $S$ flexneri infections had TNF detectable in stools (12-2545 and 25$358 \mathrm{pg} / \mathrm{ml}$ respectively; Fig 5). Two of four children with adenovirus infection also had TNF detected in stools $(10$ and $109 \mathrm{pg} / \mathrm{ml})$. In contrast none of the children with $S$ sonnei, $(\mathrm{n}=1)$ Salmonella $(n=5)$, Cryptosporidia $(n=5)$, rotavirus $(n=4)$, or children with pathogen-negative acute diarrhoea $(n=4)$ and healthy controls $(n=4)$ had detectable TNF in stool filtrates.

\section{Discussion}

Severe shigellosis may be complicated by disseminated intravascular coagulation, haemolytic uraemic syndrome, and occasionally gangrene 


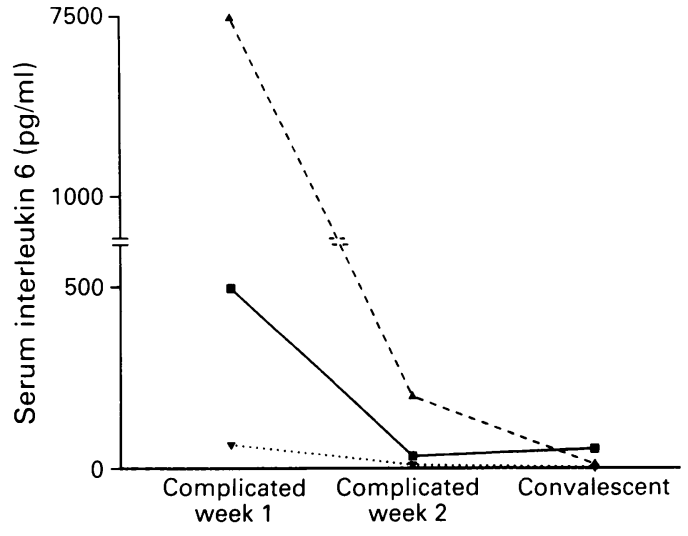

Figure 2: Serum interleukin 6 concentrations in children with complicated shigellosis in whom serum samples were available during the first and second weeks of the illness and convalescence. Each symbol represents a single patient.

and perforation of the large bowel." Endotoxaemia, ${ }^{12}$ raised fibrin degradation products, ${ }^{12}$ and deposition of fibrin in glomeruli ${ }^{14}$ and in rectal microvasculature ${ }^{15}$ have been reported in patients with uncomplicated shigellosis. Infusion of TNF or endotoxin in rabbits produced similar pathology including disseminated intravascular coagulation with thrombocytopenia, damage to glomeruli with leukocyte infiltration, segmental ischaemia, haemorrhage, and necrosis in the liver, bowel, adrenals, pancreas, lung, and other tissues.' Microscopy showed fibrin deposits, polymorphonuclear infiltration, and arterial thromboses. ${ }^{71618}$ Similarities between the pathology of shigellosis and endotoxin or TNF infusions prompted us to investigate cytokine concentrations in sera and stool extracts from children with shigellosis.

Serum IL-6 and TNF concentrations were significantly raised during the acute phase of $S$ dysenteriae 1 infection in children with a complicated course compared with convalescence, and IL-6 concentrations correlated with the presence of complications such as haemolytic uraemic syndrome, microangiopathic haemolytic anaemia, leukemoid reactions, thrombocytopenia or thrombocytosis, and severe colitis associated with persistent diarrhoea. IL-6 has been shown previously to be a better indicator of

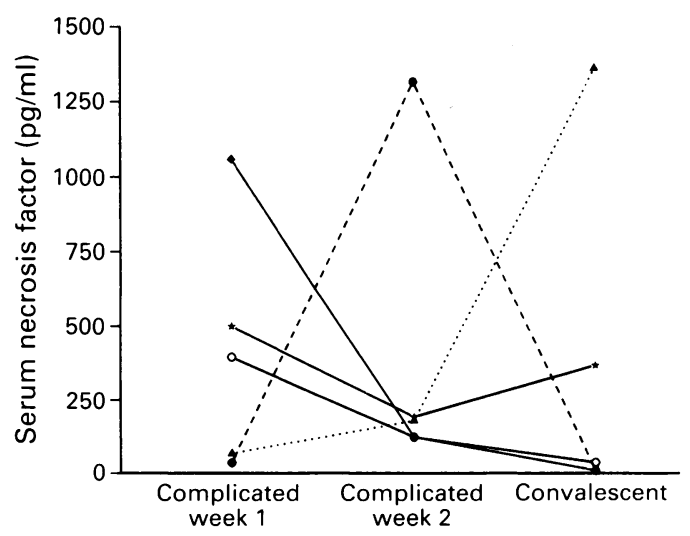

Figure 3: Serum tumour necrosis factor concentrations in children with complicated shigellosis in whom serum samples were available during the first and second weeks of the illness and convalescence. Each symbol represents a single patient. disease severity in other septic states, ${ }^{14}$." although TNF release is essential for the initiation or amplification of IL-6 release. "IL-6 and IL-1 are probably important mediators of the pathological effects of $\mathrm{TNF}^{\mathrm{*}}$ including endothelial cell damage caused by increasing the adhesiveness of neutrophils and endothelial cells, ${ }^{22}$ endothelial rearrangement, ${ }^{23}$ production of a procoagulant factor by endothelial cells, reduced expression of thrombomodulin, ${ }^{2+}$ increased production of IL-1, which can in turn activate leukocytes to initiate coagulation, ${ }^{25}$ and stimulation of endothelial cells, polymorphs, and macrophages to produce platelet activating factor. ${ }^{26}$

Although IL-6 concentrations discriminated between children with severe and mild dysentery, there was considerable variation in concentrations of IL-6 and TNF between members of the same patient groups and in individual patients studied longitudinally. By analogy, injection of endotoxin in rabbits produced a surge of TNF secretion lasting 4-5 hours and TNF secretion was refractory to a second injection of endotoxin. ${ }^{27}$ These fluctuations may not be detected unless repeated estimations are made. ${ }^{2 x}$ All children in the convalescent group had had a complicated course and had had blood taken on the first or second day of convalescence; this may explain the persistent noticeable increase in serum TNF in one patient.

The finding of IL-6 and TNF in some stool filtrates shows that the colonic mucosa was exposed to cytokines from both serosal and mucosal surfaces. The highest concentrations were found in stools from children infected with $S$ dysenteriae 1 , that is the most virulent species of Shigella. The IL-6 and TNF may have originated from blood loss or transudate from the bloodstream, but the absence in the stool of other invasive micro-organisms, and the presence of TNF in stools from children with watery diarrhoea caused by adenovirus raise the possibility of local production. Interestingly, adenovirus infection has been reported in assocation with haemolytic uraemic syndrome $e^{2, " 10}$ and other viruses can stimulate production of cytokines." The intestinal mucosa is a potential source of local cytokine production, as small intestinal cells have been shown to produce IL- $6,{ }^{\prime 2}$ and, in inflammatory bowel disease, production of IL-1 and TNF by colonic mucosae has been demonstrated. ${ }^{33}$ Extensive infiltration by mononuclear cells including macrophages was seen in mucosal biopsy specimens of the large bowel in shigellosis. ${ }^{15}$ These macrophages, stimulated by endotoxin released from invading shigellae represent a further potential source of local cytokine production."

We postulate that the degree of local tissue destruction of the colonic mucosa in shigellosis is related to the amount of Shiga toxin produced, which in turn exposes inflammatory cells, especially macrophages, to endotoxins. The local vasculitis observed in shigellosis, ${ }^{1:}$ may be related to a direct effect of Shiga toxin on endothelial cells, as shown in in vitro studies of Obrig et al, ${ }^{4}$ or caused by local cytokine production or both. TNF and IL-6 are also known to cause vasculitis." The vasculitis in turn could 


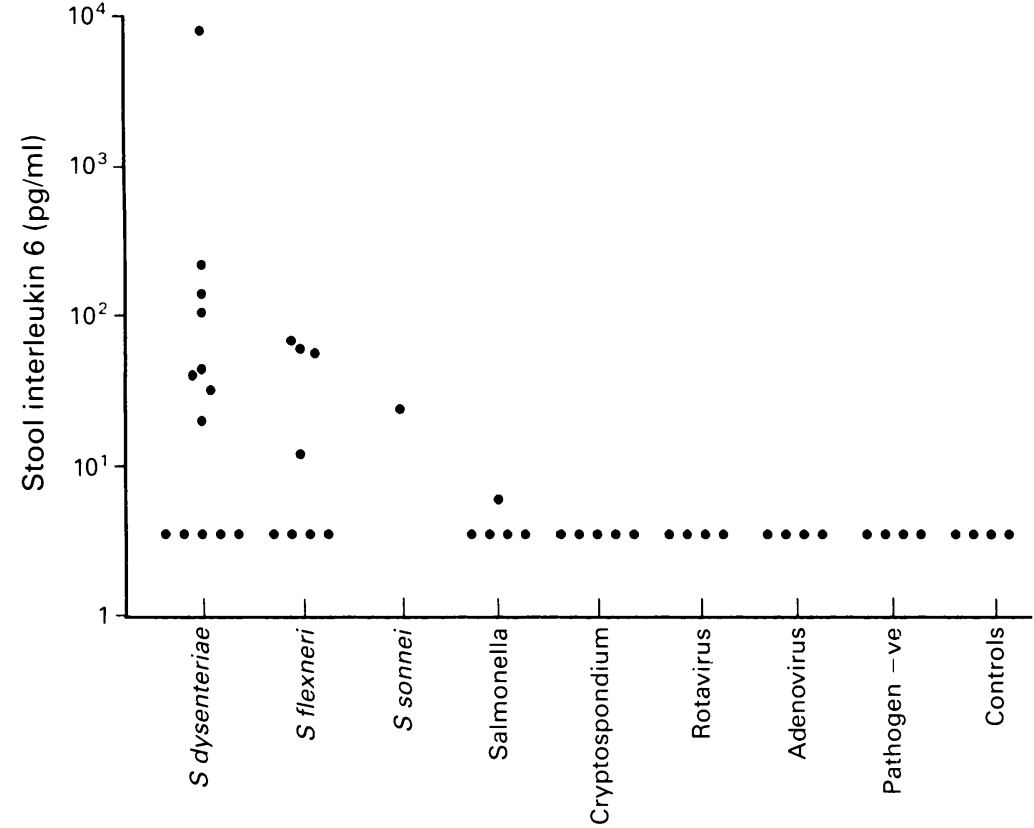

Figure 4: Stool concentrations of interleukin 6 in children with acute diarrhoea of various aetiologies. prevent disseminated intravascular coagulation and haemolytic uraemic syndrome.

We wish to acknowledge the financial support of the Association of Commonwealth Universities, Central Research Funds of the University of London and the Medical Research Council.

1 Levin M, Walters MDS, Barratt TM. Hemolytic uremic syndrome. Adv Pediatr Infect Dis 1989; 4: 51-82.

2 Rahaman MM, Alam AKMJ, Islam R, Greenough III WB, Lindenbaum J. Shiga bacillus dysentery associated with marked leukocytosis and erythrocyte fragmentation. Fohns Hopkins Med F 1975; 136: 65-70.

3 Karmali MA, Petric M, Lim C, Flemming PC, Arbus GS, Lior H. The association between idiopathic hemolytic uremic $\mathrm{H}$. The association between idiopathic hemolytic uremic
syndrome and infection by verotoxin-producing Escherichia syndrome and infection by verotoxi

4 Obrig TG, Del Vecchio PJ, Brown JE, et al. Direct cytotoxic action of Shiga toxin on human vascular endothelial cells Infect Immun 1988; 56: 2373-8.

5 Richardson SE,Jagandha V, Smith CR. Comparative pathology of hemolytic uremic syndrome associated with verotoxin producing Escherichia coli infection and experimental disease induced in rabbits by parenteral VT challenge [Abstract AMV-6] International Symposium and Workshop on Vertoxin producing Escherichia coli infections, Toronto, July 1987.

6 Butler T, Rahman H, Al-Mahmud KA, et al. An animal model of haemolytic uraemic syndrome in Shigof haemolytic uraemic syndrome in Shig ellosis:lipopolysaccharides of Shigella dysenteriae 1 and $S$.
flexneri produce leukocyte-mediated renal cortical necrosis in flexneri
rabbits. rabbits.

7 Bertani T, Abbata M, Zoja C, et al. Tumor necrosis factor induces glomerular damage in rabbits. Am f Pathol 1989, 134: $419-30$

8 Starnes HF, Pearce MK, Tewari A, Yim JH, Zou JC, Abrams JS. Anti-IL-6 monoclonal antibodies protect against lethal Escherichia coli infection and lethal tumour necrosis factoralpha challenge in mice. $\mathcal{F}$ Immunol 1990; 145: 4185-91.

produce further tissue necrosis, ulceration, and in severe cases, necrotising enteritis.

Sequestered TNF release is thought to be imported in the pathogenesis of other diseases including adult resporatory distress syndrome, ${ }^{37}$ malaria, ${ }^{38}$ meningitis,$^{39}$ and urinary tract infection. $^{+0} \mathrm{~A}$ generalised release of cytokines in shigellosis could lead to disseminated intravascular coagulation and haemolytic uraemic syndrome that is associated with $S$ dysenteriae 1 infection. Monoclonal antibodies to TNF are a successful adjunct in the treatment of septic shock. ${ }^{+1}$ Further studies on the role of Shiga toxin, TNF, and other cytokines in the complications of shigellosis are indicated since the early treatment of patients with poor prognostic signs, with anti-TNF monoclonal antibodies might

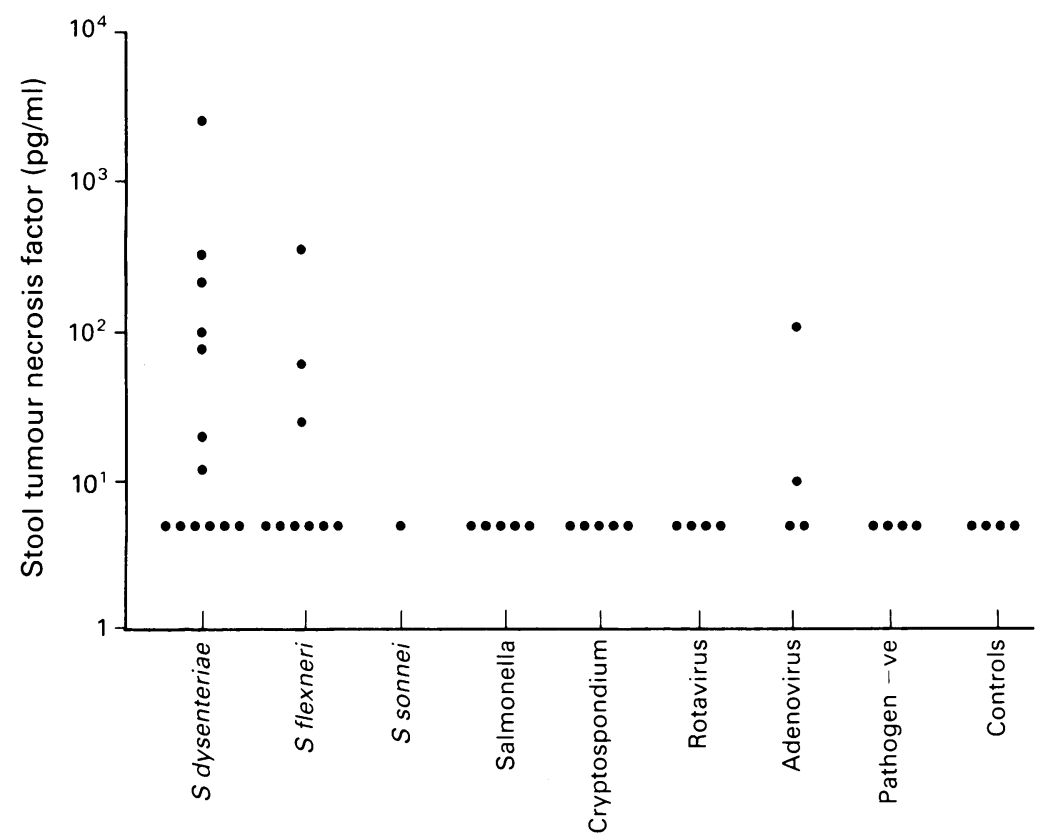

Figure 5: Stool concentrations of tumour necrosis factor in children with acute diarrhoea of various aetiologies.
9 Chart H, Scotland SM, Rowe B, Milford DV, Taylor CM. Serological identification of Escherichia coli O157:H7 infection in haemolytic uraemic syndrome. Lancet 1991; 337 . tion in $138-40$.

10 Lamabadusuriya SP, Chandrasoma PT, de Silva DDS. An epidemic of blood and mucous diarrhoea complicated by disseminated intravascular coagulation. Cevlon Med $\mathcal{F} 1984$ 29: 185-92.

11 Ruff MR, Gifford GE. Rabbit tumor necrosis factor: mechanism of action. Infect Immun 1981; 31: 380-5.

12 Koster F, Levin J, Walker L, et al. Hemolytic uremic syndrome after shigellosis: relation to endotoxemia and circulating immune complexes. N Engl f Med 1978; 298 927-33.

13 Badami KG, Srivastava RN, Kumar R, Saraya AK. Disseminated intravascular coagulation in post-dysenteric haemoly nated intravascular coagulation in post-dysenteric haemoly-
tic uraemic syndrome. Acta Paediatr Scand 1987; 76: 919-22.

14 Koster T, Boonpucknavig V, Sujaho S, Gillman RH, Rahaman MM. Renal histopathology in hemolytic uremic syndrome following Shigellosis. Clin Nephrol 1984; 21: 126-33.

15 Mathan MM, Mathan VI. Ultrastructural pathology of the rectal mucosa in Shigella dysentery. Am 7 Pathol 1986; 123 $25-38$.

16 Tracey KJ, Fong Y, Hesse DG. et al. Anti-cachectin/TNF monoclonal antibodies prevent septic shock during letha bacteremia. Nature 1987; 330: 662-4.

17 Tracey KJ, Beutler B, Lowry SF. Shock and tissue injury induced by recombinant human cachectin. Science 1986 234: $470-4$.

18 Tracey KJ, Lowry SF, Fahey III TJ. Cachectin/TNF induces lethal shock and stress hormone response in the dog. Surg Gynecol Obstet 1987; 164: 415-22.

19 Waage A, Brandtzaeg P, Halstensen A, Kierulf P, Espevik T. The complex pattern of cytokines in serum from patients with meningococcal septic shock. Association between interleukin-6, interleukin-1, and fatal outcome. $\mathcal{F} \operatorname{Exp} M e d 1989$ 169: $333-8$.

20 Hack CE, De Groot ER, Felt-Bersma RJF, et al. Increased concentrations of interleukin-6 in sepsis. Blood 1989; 74 $1704-10$.

21 Fong Y, Tracey KJ, Moldawer LL, et al. Antibodies to cachectin/tumour necrosis factor reduce interleukin-1 alpha and interleukin-6 appearance during lethal bacteremia. f Exp Med 1989; 170: 1627-33.

22 Bevilacqua MP, Pober JS, Wheeler ME, Cotran RS, Gimbrone MA. Interleukin activation of vascular endothelium: effects MA. Interleukin activation of vascular endothelium: effects on procoagulant activity

23 Stolpen AH, Guinan EC, Fiers W, Pober JS. Recombinan tumor necrosis factor and immune interferon act singly and in combination to reorganize human vascular endothelial cell
monolayers. Am f Pathol 1986; 123: 16- 24 .

24 Nawroth PP, Stern DM. Modulation of endothelial cell haemostatic properties of tumor necrosis factor. $7 \mathrm{Exp} \mathrm{Med}$ 1986; 163: 740-5.

25 Nawroth PP, Bank I, Handley I), Cassimeris J, Chess I, Stern D. Tumor necrosis factor/cachectin interacts with endothelial cell receptors to induce release of interleukin $1.7 \mathrm{Exp}$ Med 1986; 163: 1363-75.

26 Camussi G, Bussolino F, Salvidio G, Baglioni C. Tumor necrosis factor/cachectin stimulates peritoneal macrophages polymorphonuclear neutrophils, and vascular endothelial 
cells to synthesize and release platelet activating factor F Exp Med 1987; 166: 1390-404.

27 Mathison JC, Wolfson E, Ulevitch RJ. Participation of tumor necrosis factor in the mediation of gram negative bacterial lipopolysaccharide-induced injury in rabbits. $\mathcal{F}$ Clin Invest 1988; 81: 1925-37.

28 Ziegler EJ. Tumor necrosis factor in humans. $N$ Engl $\mathcal{F}$ Med 1988; 318: $1533-5$

29 Ray CG, Tucker VL, Harris DJ, Cuppage FE, Chin TDY Enteroviruses associated with the hemolytic uremic syndrome. Pediatrics 1970; 46: 378-88.

30 van Wieringen PMV, Monnens LAH, Shretlen EDAM. Haemolytic uraemic syndrome; epidemiological and clinical study. Arch Dis Child 1971; 49: 432-7.

31 Aderka D, Holtmann H, Toker L, Hahn T, Wallach D. Tumour necrosis factor induction by Sendai virus. f Immunol 1986; 136: 2938-42.

32 Schürer-Maly, Halter F, Urwyler A, Liehl E, Maly FE. Cytokines: mediators of intestinal epithelial cell growth. Gut 1991; 32: A574

33 Theis P, Korsukewitz C, Hampel KE, Müller C, Gahl GM Jörres A. Assessment of tumour necrosis factor alpha (TNF alpha) in human colonic biopsies [Abstract]. Falk Symposium No. 60, Inflammatory bowel diseases; progress in basic research and clinical implications, Freiburg, October 18-20, 1990.

34 Kawakami M, Ikeda Y, Le Trang N, Vine W, Cerami A. In:
Patton W, ed. Proceedings of the IUPHAR. New York: Macmillan, 1984: 377-84.

35 Fontaine A, Arondel J, Sansonetti PJ. Role of Shiga toxin in the pathogenesis of bacillary dysentery, studied by using a
tox- mutant of $S$. dysenteriae 1. Infect Immun 1988; 56: tox- mutant

36 Van der Poll T, Büller HR, Ten Cate $\mathrm{H}$, et al. Activation of coagulation after administration of tumor necrosis factor to normal subjects. N Engl F Med 1990; 322: 1622-7.

37 Millar AB, Foley NM, Singer M, Johnson N McI, Meager A, Rook GAW. Tumour necrosis factor in bronchopulmonary secretions of patients with adult respiratory distress syndrome. Lancet 1989; ii: 712-4.

38 Clark A, Rockett KA, Cowden WB. Role of TNF in cerebral malaria. Lancet 1991; 337: 302-3.

39 Tarlow MJ, Crocker J, Detta A, Comis SD. Choroid plexus may be important in the induction of the inflammatory response in the central nervous system [Abstract]. British Paediatric Immunology and Infectious Diseases Group, Paediatric Immunology

40 Hedges S, Anderson P, Lidin-Janson G, De Man P, Svanborg C. Interleukin -6 response to deliberate colonization of the urinary tract with gram-negative bacteria. Infect Immun 1991; 59: 421-7.

41 Exely AR, Cohen J, Buurman, Owen R, Hanson G, Lumley J, et al. Monoclonal antibody to TNF in severe septic shock [letter]. Lancet 1990; 335: 1275-7. 